\title{
Conversations with Oedipus
}

\author{
Conversando com Édipo
}

Jay Greenberg*

\begin{abstract}
As psychoanalysts engage with our patients in exploring their lives, we learn a great deal about the ways in which they express their own agency, and also about ways in which they respond to being the object of other people. But because of the particular history of psychoanalytic theorizing, we are more familiar with interpreting the patient's activity - the drives and wishes - than we are with dealing with the inevitable reversals between activity and passivity that characterize every life. This problem is explored by drawing parallels between clinical material and Sophocles' tragic rendering of the life of Oedipus the King.
\end{abstract}

Keywords: Psychoanalysis, passivity, activity.

In the opening scene of Sophocles' tragic retelling of the ancient myth of Oedipus, the hero stands in front of a group of people who have come to him for help. Thebes is in the grip of a terrible plague, famine and disease are ravaging the city, everything lies in ruin. Addressing the citizens as "children," and referring to himself as "Oedipus whom all men call great," the king promises that he will do everything in his power to save the city.

And, as all involved know well, Oedipus' powers are formidable. He has saved Thebes before, by solving the riddle of the Sphinx; that is why even though a foreigner he was made King and given the Queen in marriage. And his 20 years of rule have been wise and kind; his characterization of himself as "great" is no idle boast.

As both the characters and the audience soon find out, the plague presents another opportunity for Oedipus to use his problem-solving ability to rescue Thebes from disaster. The oracle at Delphi has given word that the plague has been sent because the city is polluted; it

\section{Resumo}

À medida que os psicanalistas se envolvem com os pacientes explorando suas vidas, aprendemos muito sobre as formas como eles expressam sua qualidade de agentes, e também sobre as formas como respondem ao fato de serem o objeto de outras pessoas. No entanto, tendo em vista a história peculiar da teorização psicanalítica, estamos mais acostumados a interpretar a atividade do paciente - seus instintos e desejos - do que a lidar com os reveses inevitáveis entre atividade e passividade que caracterizam a vida de cada pessoa. Neste artigo, essa questão é explorada traçando paralelos entre material clínico e a representação trágica da vida de Édipo Rei segundo Sófocles.

Descritores: Psicanálise, passividade, atividade.

is harboring the murderer of the former king, Laius. Salvation depends upon solving the decades-old crime and punishing the killer. Oedipus, with characteristic selfconfidence, says that he wants the people to understand that "I'll do everything" (Sophocles, translated by Grene, 1959, I. 145, p. $17^{1}$ ) to identify the killer, the citizens can relax knowing that they are in good hands. And, in one of the many ironies that give a chilling feel to the opening scene of the play, he makes clear that his own self-interest even more than the interest of the ordinary people is at stake: "For whoever was the slayer of Laius might wish to take vengeance on me also with a hand as fierce" (Sophocles, translated by Jebb, 1893, p. 312).

The plot of Oedipus Tyrannus as it unfolds tells the story of the destruction of Oedipus as he discovers what he has done and as he learns the truth about his origins, but also as he comes to confront the limits of his ability to solve problems rationally. Throughout the course of the play, Oedipus relentlessly insists, often in the face of

\footnotetext{
* PhD. Training and supervising analyst, William Alanson White Institute of Psychoanalysis, Psychiatry, and Psychology, New York, NY, USA. Editor, The Psychoanalytic Quarterly.

No conflicts of interest declared concerning the publication of this article.

Suggested citation: Greenberg J. Conversations with Oedipus. Trends Psychiatry Psychother. 2012;34(2):51-61.
} 
warnings by the other characters, on fulfilling the promise he has made to his "children." And he does, to a fault, until eventually he not only solves the crime but also discovers his own identity. By the end of the play our attention has shifted: we are no longer interested in the fate of Thebes, but in the fate of Oedipus, whose brilliance and tenacity have brought about his own ruin. The ironic truth of Oedipus' concern that "the slayer of Laius might wish to take vengeance on me" has been revealed, in a way that he could not possibly have anticipated.

So, at the end of the play, Oedipus' condition is the opposite of what it was at the beginning, in at least three crucial, related ways. First, his role as the solver of problems, the investigator, has been reversed: as events unfold he becomes the object of the investigation. ${ }^{3}$ Second, where at the beginning he saw himself and was seen by others as a god-like embodiment of virtues, at the end he is revealed as morally polluted, as the perpetrator of the worst imaginable crimes, and as the cause of the plague itself. And finally, the man who saw himself as the savior of the city has been rendered powerless and dependent on the will of others; he is led off the stage blind and helpless, awaiting decisions about his future in which he will have no say at all.

Sophocles' telling of the story of Oedipus did not, however, end with the conclusion of the Oedipus Tyrannus; he returned to it many years later, near the end of his own life. Although not quite a sequel, Oedipus at Colonus does pick up the story 20 years later. ${ }^{4}$ Strikingly, the play opens as the earlier play ended; Oedipus, now far from home, is led on stage by his daughter, Antigone. The first word of the play is, remarkably, the same word that opened Oedipus Tyrannus: "My child," Oedipus says, but the impact is the opposite of what it was the first time. Referring to Antigone as "child of the blind old man," he goes on to ask where it is that they have come to: "my child" is plaintive, helpless.

But, as the plot of the play unfolds, Oedipus' fortunes change once again. He remembers that decades earlier, when the Delphic oracle had told him that he was doomed to murder his father and to have children with his mother, there had been another part of the prophecy. After, and perhaps because of, his years of suffering, he is destined to achieve a power greater than any he had experienced before. He will be, as he puts it:

\section{a blessing to the hosts I live among,}

disaster to those who sent me, drove me out.

(Sophocles, translated by R. Fagles, 1984, II. 113-45)

Oedipus has been told, and has come to believe, that at the end of his life and in death he will have the power to protect the city that has taken him in and buried him.
And at the end of Oedipus at Colonus we see the hero transformed once again. Aware that the time of his death has arrived, he turns to his daughters:

Follow me, o my children

come this way. I stand revealed at last, look, a strange new role for me - I am your guide as you were once your father's. (Sophocles, translated by R. Fagles, 1984, II. 1749-535)

The reversals of fortune that run through the story of Oedipus from his birth to his death and beyond have, since Aristotle, been considered one of the central characteristics of tragic narrative. Aristotle's definition was somewhat narrowly cast; for him, reversal is: "the change... from one state of things within the play to its opposite... The perfect plot... must have a single... issue; the change in the hero's fortunes..." (Aristotle, 1941 , I. $\left.1453 a^{6}\right)$. The impact of tragedy, Aristotle went on, hinges on engaging the audience as witness to this change in the hero's circumstances.

A great divide separates the world of the tragedians of 5th century Athens from that of the contemporary psychoanalyst, so at first glance neither they nor Aristotle seem to have very much to teach us, especially with respect to our clinical work. Perhaps what separates us most is that the tragedians had little interest in peoples' inner lives; their intention was not at all psychological in any way that we think of psychology today. And of course the Greek authors lived with and wrote about gods and heroes; they elaborated myths and legends that, over the course of countless generations, organized the lives of people living within a fixed, although evolving pattern of social organization. The psychoanalyst, in contrast, focuses on the fate of ordinary people struggling to live ordinary lives. And our culture could not be more different than that of the ancient Greeks. Analysts and their patients alike are immersed in a society where change is the order of the day, structure is always up for grabs, and everything depends on the newest developments in technology, politics, and cultural trends.

Because of broad trends in the sociology and politics of contemporary academic and scientific discourse, we have moved away from our engagement with the ancient texts, away even from any idea that psychoanalysis is, as Roy Schafer has suggested, a narrative discipline. ${ }^{7}$ We rarely look beyond clinical process, and when we do we are likely to turn to and to embrace a laboratory-based empiricism that we hope will support what we have learned from working with patients. But in turning our gaze toward the laboratory, we lose sight of something crucial: despite the exciting findings in neuroscience, or infant observation, or other adjacent disciplines, the 
ideas that we think about and work with every day have been thought about for many thousands of years, and in surprisingly similar ways. As I see it, the opportunity to engage with and to apply these ideas is one of the privileges of being a psychoanalyst today.

The turn away from the classics and from narrative generally means that we have turned away from the origins of our discipline. Psychoanalysis began with the idea that neurotic symptoms were fragments of a life history that, because of the mind's capacity for repression, had been wrenched out of their context. Without context, symptoms were signposts that pointed nowhere because they had been torn out of their landscape; they could do nothing but frighten and oppress the patient, bringing psychic or physical debilitation. The cure for this, Freud quickly came to believe, was to restore context, and doing this required telling a story that would give meaning to what had appeared - both to the patient and to the world - inchoate and disturbing. Connecting the symptoms in a compelling way to the known events of the patient's life would provide a narrative structure that could explain what had appeared inexplicable. The explanations, in turn, led to self-understanding, which, by empowering the patient to exert influence over the events of his or her own life, would bring about a cure through mastery. This idea - that good stories allow us to understand what had seemed strange and terrifying and that understanding is a first step toward control runs through human history from its very beginnings. Freud's brilliant coup was to see that what story-tellers and myth-makers had always done for their societies could work, on a smaller scale, for individual sufferers.

The first preserved record of a Western society creating stories for the purpose of making sense of both the natural world and of human experience can be found in the epics, lyrics, and tragedies of ancient Greece. In these works, we can see the most creative representatives of a society grappling with the need to understand themselves and their world, and doing so without any technology beyond human reason and ingenuity. So it is not surprising that Freud quickly turned to the Greek tradition to find support for his project. Very shortly after arriving at the general conclusion that stories could cure, he turned to Sophocles' version of the Oedipus myth as the primal narrative around which to erect his theoretical structure.

Aristotle, like Freud, believed that Oedipus Tyrannus was the most perfectly formed of the Greek tragedies. But he approached the play strictly from a dramatic perspective; it is only comparatively recently that readers have mined Oedipus or any of the ancient texts for their psychological implications. Friedrich Nietzsche, perhaps the most influential figure in developing the modern understanding of tragedy, reformulated Aristotle's idea of reversal in a way that suggests deeper psychological possibilities. Commenting on Oedipus - and pointing to the trajectory that runs from the beginning of his life to its end at Colonus - Nietzsche wrote: "... the hero, through his passivity, has found his supreme activity, the effects of which will resonate far beyond his own life, while his conscious strivings in his former life led him only to passivity" (Nietzsche, 1870-1, p. 478). Activity and passivity refer to inner states of mind as well as to ways of behaving in the world. Nietzsche's way of conceptualizing tragic reversal gives psychological change the same central role that Aristotle had given to change in the tragic hero's circumstances, prefiguring Freud's invention of the Oedipus complex, which gave psychological meaning to what for the Greeks was a legal and religious matter.

The more psychological account of reversal leads to another, also modern, understanding of the tragic vision. Consider what the historian of tragedy, Jean-Pierre Vernant, has written: "... tragedy presents individuals engaged in action. It places them at the crossroads of a choice to which they are totally committed; it shows them on the threshold of a decision, asking themselves what is the best course to take." And this decision always involves risk, because its outcome is significantly dependent on the will of the gods. Thus, the action that is the subject of tragedy is "a kind of wager - on the future, on fate and on oneself... In this game, where he is not in control, man always risks being trapped by his own decisions" (1990, p. 449). The reversals from activity to passivity - Nietzsche's psychological reframing of Aristotle's original formulation of the essence of tragedy - follow the risky, committed choices that we all must make and that, taken together, constitute our lives.

Risk and changing fortune: what better way to conceptualize the themes that psychoanalysts work with every day?

\section{Clinical material}

Angela, a married woman approaching middle age who has lived a severely constricted, nearly agoraphobic life for many years, has recently developed an interest in contemporary art. She follows news reports of events in the art world, participates in internet chats about art, buys books with reproductions of the latest paintings and sculptures.

Angela would love to visit New York's art galleries, but she cannot bring herself to do so. Sometimes she goes down to Chelsea or to Madison Avenue and stands outside the galleries, but she doesn't enter them. She 
can't bear, she says, the scrutiny of the people who work there. Certainly they will know immediately that she can't afford to buy anything, and they will quickly figure out that she doesn't even know very much about what she is looking at. They will know that she doesn't belong, and they will disdain her for being where she should not be. Angela guesses that she will pick up their scorn because she is exquisitely attentive to nuances of tone and/or facial expression, but she also fears that perhaps she will not notice. That would be even worse, because then she would be left unable to protect herself against their contempt.

And there is something more that Angela is worried about. Sensing the contempt and revulsion that she is sure others will feel toward her, she knows that she will become angry, even hateful. This will further disenfranchise the other, something that has happened many times before. So she is frozen; she can neither act nor risk being acted upon.

Somehow, after many false starts over the years, Angela has managed to enter and to continue in analysis, although her participation comes at a price. Forever fearful of my judgment of her, she has worked out ways that she hopes will limit my freedom to respond; she constrains her associations, mainly talking about her frustration and despair and about the hostility of her husband and the few other people with whom she has any contact. Often, I step out of bounds - for instance by wondering whether she does anything that contributes to the way her life has worked out or by suggesting that perhaps change is possible. When I do this, Angela rages, or retreats into wounded hurt, or stays away from sessions for a week.

In this way, Angela creates a situation that reminds me of the one she is in when she stands outside the art galleries. She gets as close as she can without actually going through the door, because she cannot risk exposing herself to my unpredictable reactions, and because she knows that she will attack me both for what I think and for what she believes I intend. And her hatred, she is sure, will drive me away. As a result, for Angela, analysis tends to be less a process of discovery and more a soothing exercise, both about myself and about her. To risk discovery is to risk allowing each of us to act upon and react to each other with a freedom that she finds terrifying.

Most analysts would, I suspect, agree that for Angela to change she will have to gain a greater sense of control over the anxiety she feels about being rejected, or disdained, or even despised. And she will also have to gain a sense of control over her own actions; she will have to hate less and understand more. There are many psychoanalytic terms that describe this change: developing a stable ego or a more benign superego, reaching the depressive position, achieving object constancy, developing the capacity for mentalization, and so on. But beyond these technical formulations, and beyond our in-house debates about the nature of therapeutic action, lies a truth that the tragedians knew well: in order to claim a sense of agency that will make it possible for her to live more effectively in the world, Angela will have to risk a new kind of action.

And the risk goes beyond merely behaving differently than she has before; Angela's new action will inevitably make her the object of others (including, perhaps most importantly, myself), and she has no way of knowing in advance - or, perhaps, ever - what those intentions are. She will have to venture into the art gallery and into her analysis, exposing herself to others in all their unpredictability. She must, in Vernant's terms, allow herself to chance this "wager - on the future, on fate and on oneself," and in Nietzsche's terms she must place herself in the passive position - that is, in the position of being the object of unknowable others - in order to find herself as an active agent. To achieve control, she must surrender her power to control.

The idea that the feeling of power and the recognition of its limits go together inseparably is what gives shape to the story of Oedipus' life, as Sophocles narrates it over the course of the two plays. Seen in overview, Oedipus lived a life characterized by reversals (as Aristotle saw it) - specifically, in Nietzsche's terms, reversals between activity and passivity, with each stage preparing him for the next. Born as an unwanted intruder who threatened the safety of those closest to him, his parents bound his feet and sent him to be left on a mountain, to die of exposure. His name, as he tells Jocasta, is based on this primal violence: oidi, meaning swollen, the root of the English word edema, and pous, meaning feet. But there is also another resonance in Oedipus' name, not explicitly mentioned in the play, but the subject of many puns throughout the text that have been noted by contemporary classicists (Ahl, 1991, p. 26, p. $182^{10}$; Knox, in Sophocles, $1984^{5}$ ): oide, coming from the verb to know, and, again, pous, or foot.

This ambiguity in Oedipus' name sets up not only the tension but the essential dialectic between activity and passivity - between agency and being the object of the agency of others - that characterizes the course of his life, and Angela's, and the lives of all of us.* Oedipus begins life as the child who is feared and despised, helpless in the face of his parents' murderous power, and he grows into the man who can save Thebes by answering

\footnotetext{
* It is not the only source of ambiguity in Sophocles' text. Note the occurrence throughout the play of references to Oedipus' feet, which suggest his maltreatment by others, and to his hand, which symbolizes his impressive powers to solve problems.
} 
the riddle of the Sphinx - a riddle that addresses the dilemma of human identity by asking a question about feet: "What animal walks on four feet in the morning, two in the afternoon, and three in the evening, and is weakest when it walks on most?" So Oedipus the baby whose feet were deformed in the service of the needs of others grows into Oedipus the man who can save the lives of others precisely because he "knows feet."

Oedipus' brilliance is of central importance to most if not all of the classicists who comment on Sophocles' play. Although tragically limited, it is the source of the greatness to which he refers at the beginning of the play. But that brilliance itself is the direct consequence of his treatment by others; throughout we learn that he has been thwarted in his efforts to get either mortals or gods to be straightforward about his identity. This aspect of the story, which has not been emphasized, should be of interest to contemporary psychoanalysts.

After being taken in by his adoptive parents Polybus and Merope, the King and Queen of Corinth, Oedipus was treated by them as a biological child. He believed this version of his birth - a belief fostered by what the Roman poet Statius described as "Polybus' deceit" (1995, p. $7^{11}$ ) - until, late in his adolescence, he was at a banquet and a drunken stranger shouted out that he was not the "true son" ${ }^{4}$ of his father. The next day, he went to his parents and, as he puts it:

questioned them closely, and they were enraged at the accusation and the fool who let it fly. (Sophocles, 1984, II. 863-45)

This is a notably odd response; Oedipus' parents do not explicitly deny the stranger's version of his birth nor do they make any great attempt to reassure their son; instead they express outrage directed toward the stranger. ${ }^{+}$Perhaps because of the ambiguity of this response, Oedipus says that:

... still this thing kept gnawing at me,

... I had to make my move. (II. 866-75)

And his move was to leave home without telling his parents and to journey to Delphi to ask the same question to the oracle.

But, strikingly, his attempt to find out who he was was thwarted by the gods, just as it had been by his parents:

... the god Apollo spurned me, sent me away

denied the facts I came for. (II. 869-705)

\footnotetext{
† The failure to rebut the stranger's accusation is clear in all translations.
}

Instead of answering the question, the oracle responded with the famous curse: that Oedipus would kill his father and marry and bear children with his mother. Thus, the curse was combined with the refusal to provide Oedipus with the information he needed.

This pattern - Oedipus asking a question about his identity and being denied an answer - is repeated in the action of the play itself; the repetition points to its important causal role. When he questions the prophet Tiresias, whom he hopes will know who murdered the former King, Tiresias is reluctant to answer but at one point mentions having known Oedipus' parents. Shocked, Oedipus says "Wait... who is my father?" to which Tiresias replies "This day will bring your birth and your destruction" (II. 498-9, p. 1845).

So by the time Oedipus Tyrannus opens, the hero has been exposed to the murderousness of his biological parents, the deceit and evasions of his adoptive parents, and the denial and curse of Apollo. This is the passivity to which Nietzsche referred; as psychoanalysts today would put it, he has been the object of the will and intentions of others. But it is just this treatment that has made Oedipus what he is - the man who knows feet, who is an expert on the mystery of human identity. The man whose identity has been kept from him by mortals and gods alike is the man who will be able to save Thebes by solving the riddle of the Sphinx; it is precisely how he has been treated by others that uniquely suits him for his great act of agency. ${ }^{*}$

But if Oedipus' agency follows from the way he has been subject to the acts of others, his activity itself catapults him into a passive role. By solving the riddle and killing the king - acts that express two outstanding aspects of his character, his brilliance and his aggressive impulsivity -, Oedipus has created a need in others, in the citizens of Thebes, which they then insist that he meet. As he says, he neither sought nor particularly wanted either the kingship or the marriage to the Queen that came with it; these were forced on him by the people of the city, who needed a leader.

We see Oedipus in the passive role most poignantly at the end of Oedipus Tyrannus and at the beginning of Oedipus at Colonus. In both, his fate is in the hands of others. But this leads to his discovery, at the end of his life, as depicted in the latter play, of what Nietzsche called his "supreme activity." The discovery comes about simultaneously with Oedipus' recognition, for the first time in his life, of the limits of his agency. The man who

\footnotetext{
\# The classicist Daniel Mendelsohn sees the trajectory of Oedipus' life similarly, although he highlights very different themes. As Mendelsohn puts it: "only Oedipus, who was, catastrophically, too many things at once to too many people, intuited that all these things [the different images of man in the riddle] were one... Only multiplex Oedipus knew that a single person could be many secret things at the same time" (1999, p. 3312).
} 
had believed in the absolute power of his rationality and, equally, in the absolute inevitability of his guilt has come to see himself in a very different light:

my acts, at least

were acts of suffering more than actions outright.

he tells the people of Colonus (Sophocles, translated by R. Fagles, 1984, II. 285-65), and later:

I have suffered it all, and all against my will!

Such was the pleasure of the gods... (II. 1098-95)

And of course he is correct. He has been subject to the will of the gods, who have placed a curse on him for reasons that no mortal can discern. He has not been as powerful as he imagined himself to be, and he has not until this moment recognized his limits. But, paradoxically, with that recognition comes a new sense of agency. As the Victorian classicist Richard Jebb put it, "he has come to look upon himself as neither pure nor... guilty" (1893, p. xxii ${ }^{4}$, my emphasis). True, he has committed the worst imaginable crimes, but he has also been subjected to the worst imaginable treatment by others. Only by knowing both can Oedipus come to truly understand himself. The hero whom "all men call great" movingly captures the importance of knowing what has been done to him when he says to his daughter, Ismene: "So, when I am nothing - then am I a man?" (Sophocles, 1984, II. 430-15).

\section{The complementarity of classics and psychoanalysis}

As Angela stands at the door of the art gallery, she is preoccupied with what will happen to her if she risks entering. For her to move forward - into the gallery or into her life - she must act. But, like Oedipus, at the moment she acts she will submit herself to the acts of others, which in turn will lead to reversals in both her situation and her frame of mind. This is what Angela cannot bring herself to do, and this is what psychoanalysis should try to help her to do. We should try to help her not just to own her own desires, which is what we have done best historically, but also to live in the alternations from activity to passivity, from being subject to being object, that the tragedies so powerfully illuminate. And we must help her to do this while fully recognizing that neither we nor she can know what is going to happen next.

Another way of putting this is to say that, standing in front of the gallery door, Angela must make Vernant's "wager on the future"; she stands on the brink of action and must choose what to do, just as the tragic heroes were bound to choose. But, unfortunately, it is at this point that Freud's reading of Oedipus, which bestrides and burdens psychoanalysis, distracts us from the problem that Angela faces.

The story of Oedipus has been characterized, aptly, as a kind of Rorschach's blot. The basic structure, an abandoned child inadvertently kills his father and marries his mother, exists as a folktale in societies throughout the world; in the ancient Greek tradition, it has been rendered in both epic and tragic versions. Each telling of the tale emphasizes different elements of it, and elements can be added or subtracted in accord with the intentions of the artist. These intentions have changed over the millennia; in the 20th century, the Oedipus myth was most famously used by the structural anthropologist Claude Levi-Strauss and by Freud, the two very different tellings designed by each to promote their largest theoretical project.

Freud's largest project, of course, was to establish wish fulfillment as the universal motive of our dream-life and, beyond that, as the motor that drives all mental activity. That is why his fullest and most influential interpretation of Oedipus Tyrannus appears in The interpretation of dreams, ${ }^{13}$ in which he argues that the trajectory of Oedipus' life - his destiny, as Freud put it - reflects the working of disavowed wishes harbored by all of us. Sophocles' Oedipus lived out the fate that we all fear, because he wanted what we all want. Doomed to realize wishes that remain fantasies for the rest of us, in the end Oedipus is destroyed by a guilt that we all feel but that has less disastrous consequences for us because we are saved by our capacity for repression.

Freud's dreamer is always the agent, never the object, just as Oedipus tried to be in Oedipus Tyrannus. That is what it means to say that dreams are always not just sometimes - wish fulfillments. Responsible for everything, and proclaiming himself uniquely capable of bearing the suffering that his guilt demands, both Oedipus and Freud's dreamer (who is, more often than not, Freud himself) locate the problem in the core of the self. For the unpsychological Greeks, this meant that Oedipus was morally and religiously polluted; for Freud, it pointed to the irrationality of our desire and to the anxieties to which irrational wanting can give rise.

If our irrational core - which Freud thought was represented by fate in the tragedies and by wishes and eventually drives in psychoanalysis - is the problem, then rational control - represented by self-awareness - must be the solution: "Turn your eyes inward, look into your own depths, learn first to know yourself! Then you will understand why you were bound to fall ill; and perhaps, you will avoid falling ill in the future" $\left(1917\right.$, p. $\left.143^{14}\right)$. So 
if the Oedipus Complex is the disease, knowing yourself is the cure; both borrow from the Greeks.

"Know yourself" (gnothi seauton) was the inscription in the Temple of Apollo at Delphi, where Oedipus learned from the oracle what his fate would be. But just what is implied by the edict is not clear, and contemporary psychoanalysts have a lot to learn from what the ancient Greeks had in mind. When Sophocles wrote Oedipus Tyrannus, the meaning of the phrase was a matter of considerable debate. An ancient aphorism, gnothi seauton had, as the political philosopher Joel Schwartz put it, "been a call for restraint and piety. Know thy station as dictated by the gods; practice... humility and cautious prudence, for the fate of man, creature of a day, is in the hands of the gods. Know thy limits" (1986, p. $187^{15}$ ). But by the latter part of the 5th century, in the midst of a period of enlightenment that had brought tremendous advances in medicine, mathematics, and other sciences, the meaning had changed. Proclaiming the power of rationality, the sophist Protagoras advanced the doctrine that "Man is the measure of all things," and when the 5th century Greeks, to quote Schwartz again, "looked into their souls, they saw power, not limits - the power to diagnose the natural causes of disease and war and the purely human ingenuity to cure them" (p. $187^{15}$ ).

In the way he cast both his theory and his clinical method, Freud adopted and promoted the later, enlightenment view of gnothi seauton: know the power of your unconscious wishes to shape your world. And know that by knowing them, you can cure yourself. This is what Oedipus initially believed; it led him to undertake what Freud called "a process that can be likened to the work of a psychoanalysis" (1900, p. 261-213). But it is a rather peculiar analysis for Freud to claim as a paradigm; at least at first, knowing himself didn't work out very well for Oedipus. "Turning inward" - learning where he had come from and what he had done - led only to guilt and despair.

The self-blinding at the end of Oedipus Tyrannus, along with Oedipus' insistence that only he will determine his fate and that only he is strong enough to bear the suffering, reminds me of many analysands' belief in their all-encompassing guilt and responsibility for everything that has happened to them. This belief masks and supports an underlying grandiosity, and is a phase in many analyses. But, to say the least, it would not constitute the sort of outcome one would think of as exemplary.

The problem - for Freud's reading of Oedipus and more broadly for his psychoanalytic vision - was the assumption that knowing yourself is exclusively a matter of turning inward, of recognizing the irrationality of your unconscious wishes and of the acts to which they give rise. Sophocles, living with and writing about the ambiguous meaning of gnothi seauton, created a narrative in which Oedipus' misery goes unrelieved until the end of his life as portrayed in Oedipus at Colonus. Only then does the hero achieve the peace of mind and sense of empowerment that we might hope for at the end of an effective analysis. And these changes, as we have seen, require that Oedipus come to know not only what he has done, but the ways in which he has been subject to the intentions - often irrational in their own right - of both mortals and the gods.

The classicist Charles Segal has addressed the differences between tragic and psychoanalytic visions of the irrational in an intriguing way. Consider this stunning passage: "For Sophocles... the irrational really is an other, an aspect of the divine outside and apart from man. For Freud, the other is projected inwardly, as part of our own mind, something hidden within ourselves" (2001, p. 42, emphasis original ${ }^{16}$ ). ${ }^{\S}$ I am struck in reading this both by the contrast Segal draws and by his generative misunderstanding of psychoanalytic terms. No psychoanalyst, of course, would say that we "project" from outside to inside (Ferenczi coined the term "retrojection" to describe this process, but it has hardly been used since). But in talking this way, Segal is, probably inadvertently, pointing to a defensive use of theory, in which it is assumed that, if we can free ourselves of irrationality, we can be sure of our ability to live freely and effectively in a rational world.

Both psychoanalytic theory and clinical practice are infiltrated, in ways that are not always fully apparent, by the assumption that the irrational is exclusively or at least primarily internal. Consider, as an example of the workings of this assumption, Kurt Eissler's concept of parameters. Eissler, discussing the analysis of phobias, begins by noting that sometimes "interpretation does not suffice as a therapeutic tool" (1953, p. 10820), by which he means interpretation of wishes and defenses against them. Despite analyzing everything that can be analyzed, the patient remains phobic. At this point, a new type of intervention is necessary: "The analyst must impose on the patient a command: to expose himself to the dreaded situation despite his fear of it and regardless of any anxiety which might develop during that exposure" (p. 10920).

This 50-year old idea has been widely and justifiably criticized on technical grounds, but its relevance here is not narrowly technical. Rather, what I have in mind is

$\S$ The idea that the irrational is, originally, located in the intentions of an external other has been emphasized in French psychoanalysis, especially in Lacan's concept of the "enigmatic signifier,"17 which has been modified and elaborated by Laplanche. ${ }^{18} \mathrm{~A}$ similar sensibility is implied, although more narrowly, in Sullivan's idea that the child empathizes with the anxiety of the mother. ${ }^{19}$ 
Eissler's assumption that, if we insist that the patient face the phobic situation, it will become clear that the felt anxiety is unfounded, because it is based on archaic beliefs about irrational desires. We believe, reasonably, that when the patient crosses the "dreaded" bridge, the bridge will not collapse, and the patient will have a new context for the anxiety that makes more adaptive behavior possible and that perhaps will even lead to new insight.

But can we honestly convey the same certainty to Angela, when she stands at the gallery door or when she fears open-ended analytic engagement? Bridges are among the greatest achievements of human rationality; crippling fear of them highlights our capacity to project our inner anxieties out into the world. A bridge phobia is an iconic example of how internal processes give shape to the external landscape. Gnothi seauton, Eissler says; "look into your own depths" to find the irrational, and once you do, you will at last be able to live safely in a predictable world. The tragedians knew that this is wishful thinking.

\section{The clinical encounter}

Once, in a moment of intense irritation with a patient, not Angela, I said: "if you're ever going to get to yourself, you'll have to go through me!" What I meant, or, more accurately, what I have come to believe I meant, was that this patient was warding me off, struggling to avoid any awareness that I was having an impact on her. I suspect that I also was thinking, although even less consciously, that she would have to tolerate a certain amount of passivity before she could find her own agency. This somewhat rougher version of Emanuel Ghent's idea that the patient must surrender to the analytic process and even to the analyst in the service of achieving autonomy recalls the trajectory of Oedipus' life through the two plays of Sophocles. ${ }^{21}$

The denial of impact is a familiar issue in all analyses (usually conceptualized as resistance, or enactment, or something of the sort), and every school of thought has a range of dynamic formulations that attempt to capture what is at stake for analysands when they are engaged in pushing their analysts away. Getting beyond the specifics, we can say that our analysands struggle to avoid the experience of becoming our object, of opening themselves to intentions of ours of which they cannot possibly be aware, and of which we are unlikely to be fully aware either.

We are not in the habit of thinking that we act on our patients in ways that make them our objects, but we do, regardless of whether we or they are consciously aware of it. Consider what is involved when analysts do even what we are most widely authorized and expected to do, interpret. In interpreting, as Charles Spezzano has put it, we let our analysands know that we think "that they don't know what they are talking about, don't mean what they think they mean, are revealing aspects of the workings of their own minds they don't know they are revealing; that they want what they don't know they want, that they are afraid of things they don't know they are afraid of..." (2007, p. $1574^{22}$ ). No wonder, then, that Spezzano concludes that interpretation is a potentially violent act (p. 157922).

In today's climate, with a wider range of the analyst's actions and reactions acknowledged, tolerated, and even encouraged, we can recognize just how perilous becoming the analyst's object can be. We do much more these days than interpret: we question our patients, which can suggest misunderstanding or disbelief; we may remain silent, which can seem rejecting; we may intentionally or inadvertently reveal an emotional reaction, which can be wounding. The inevitability of confrontations with the mind of the analyst led the French analyst Jean Laplanche to conclude that it is a crucial aspect of the psychoanalytic situation that "there is the traumatic element... of the subject faced by the enigma of the other" $\left(1992\right.$, p. $12^{18}$; note the similar sensibility in Smith ${ }^{23}$ ).

The psychoanalyst Laplanche, working clinically, discovers the traumatic impact of "the enigma of the other"; the classicist Segal, reading ancient texts, concludes that, for the Greek tragedians, "the irrational really is an other." The classicist knows that, in the face of irrationality, the tragic hero must act; the psychoanalyst knows that, in the face of the enigmatic other, the analysand must speak - speech being, of course, the most prominent form of analytic action. Both the psychoanalyst and the classicist know that to act means to expose oneself to the other - to the enigmatic and to the irrational. Both know, at least implicitly, the risks that this involves, and both know that the act will initiate a series of acts the nature and consequences of which cannot be foretold.

When Segal and other classicists talk about the irrational, they are using a word that we psychoanalysts do not easily apply to ourselves. But everything we do has unconscious determinants, and certainly, from our patients' point of view, we are irrational, in the sense that it is impossible for them to know our minds or to predict how we will respond to them. Our patients cannot know, when we act, what thoughts and feelings lie behind our actions. Nor is this something that they can ever learn, once and for all. As analysis proceeds, the analysand's claiming him or herself in new ways 
will evoke new reactions in the analyst; each advance is going to make the analysand their analyst's object in novel and unpredictable ways. Our irrationality, and thus the traumatic undercurrent, is present in every moment of every analysis. Let me be clear in putting things this way that, from the perspective I am describing and advocating, the analyst's irrationality is a powerful force in the analysis, even at those times when the analyst at least from his or her own perspective - is behaving rationally.

So two central elements of the tragic vision shed light on crucial aspects of the analytic encounter: the reversals that play out in the constantly shifting pattern of being subject and object, and the risks that are entailed in choosing a course of action when to act means to become the object of an unknown and irrational other. Although these are rarely theorized and are not often addressed directly between patient and analyst, they do tend to generate considerable anxiety in both participants.

The patient, not knowing and needing to act in the face of the irrational, struggles to impose certainty and rationality on a situation where none exists. The psychologically-minded classicist E.R. Dodds has addressed this problem with respect to the tragedies. Dodds notes that readers of Sophocles' Oedipus, trying to understand why he has been subjected to his terrible fate, create ideas like "divine justice" to make what has happened comprehensible. But, he goes on, this sort of belief is an inadequate human invention, representing a futile attempt to explain the unknowable other by applying standards that are familiar to us. The will of the gods, Dodds argues, does not fit any way of thinking that mortals can know; it simply is (1966, p. $180^{24}$ ).

We no longer believe in gods in quite the way that the Greeks did, but we do live in a world of motivated others, including motivated analysts, and typically we do not understand the motives that affect us most. And because we live with this constant although largely unconscious uncertainty, we create templates, similar to notions of divine justice, in our attempt to understand what cannot be understood but must be coped with. This human capacity is what psychoanalysts know as transference. Harry Stack Sullivan's understanding of transference, which he characteristically but insignificantly renamed "parataxic distortion," emphasized the value of transference in helping us to navigate through unknown territory that is shaped by the inscrutability of motivated strangers, analysts and others alike. ${ }^{25}$

Like patients, analysts retreat from full awareness of how traumatizing the psychoanalytic encounter can be. A great deal of clinical theory prescribes a role for the analyst that is designed to alleviate the anxiety inherent in fully appreciating the impact of risk and reversal. Our leading technical prescriptions - that we be neutral, or empathic, or that we function as containers, or that we should think of ourselves as experts in interpersonal relations, or that we should embrace and strive for intersubjectivity - all serve this role. Each prescription suggests that the analyst can operate from a fixed position that the analysand can count on, enabling the analysis to proceed with minimum risk. And, if the analyst behaves in accord with proper technique, it is assumed, any felt risk can be attributed to the irrationality of the analysand.

The analysand enjoined to "know yourself" is being asked to assume that whatever he or she makes of the analyst comes from inside. Analysands must come to know their power (the later version of gnothi seauton) to shape their personal experience of the analyst and the analytic situation. Interactive accounts of the psychoanalytic situation - as developed in the Kleinian, interpersonal, and relational traditions - actually expand the scope of the analysand's power to include the ability to influence the experience and/or behavior of the analyst.

But things look very different if we accept that analysts are personally motivated, that their motivations render them enigmatic to their analysands (as Laplanche notes), and that consequently they are always potentially violent (in Spezzano's terms). This more tragic vision of the psychoanalytic situation has profound implications for our analytic goals: while it remains crucial for analysands to become aware of their own power, focusing exclusively on this puts us at risk of overlooking the wisdom of the earlier version of gnothi seauton: know your limits. That is, it is equally important for analysands to become aware that they are in the presence of an other, whose intentions and the impact of whose actions they will never really know and whose object they will become, in ways that neither participant will ever fully grasp.

Recently, I asked Angela to make a permanent change in a regularly scheduled appointment. Somewhat uncharacteristically, she agreed without too much protest and without asking why I needed to do so. Two sessions later, she reported a dream: I was moving either my home or my office, she wasn't sure which. I would be in a building not too far from where she lived. In the dream she knew why I was moving, although upon awakening she couldn't remember the reason. What she did know, and fear, was that I would be suspicious of how she had found out. Recounting the dream, Angela said that she had actually been worried about my changing the appointment. She was especially worried about not knowing why I had asked for the switch. But at the time, she hadn't thought to ask.

The dream reminds me of Angela's problem as she stands outside the doors of art galleries. There she, like 
Oedipus standing before the Sphinx, knows too much. Oedipus knows what his brilliant intelligence can discern about the meaning concealed within an apparently inane riddle. And Angela knows what a lifetime of experience has taught her: that the gallery employees will feel contempt for her, that they will express it in veiled ways that will be revealed only if she exercises exceptional vigilance, and that her safety and even her survival depend on her being able to control the situation by taking steps to avoid the dangers within.

But also like Oedipus, Angela tragically knows too little. Oedipus, the expert on identity, knew that the answer to the riddle of the Sphinx was "Man." But he did not know that the truer, deeper answer was "Oedipus," that it was his feet to which the riddle referred, the trajectory of his life as described in Oedipus Tyrannus, from mutilated and abandoned child, to tyrant, to the ruined blind man who must rely on a cane and his daughter to walk. And, tragically, he knew nothing about the chain of events that his answer would set in motion. Similarly, Angela cannot know that the answer to what she feels outside the gallery door is "Angela." The deeper solution to her dilemma does not lie in her power to find a "right answer," a way of behaving that will allow her to control the responses of others as Oedipus' "right answer" led the Sphinx to destroy herself. Rather, it lies in opening herself to the consequences of her own personal history - the history of what she has wanted and the history of what has been wanted of her.

So, Angela, like Oedipus and in one way or another like all our patients, knows too much and too little, simultaneously. Both believe in their capacity to control their lives through knowing, and both believe that they are in control, although Angela's experience is tainted by her desperation. But neither knows as much as they think they do about themselves or about their place in the world; in their very different ways, neither knows how their lives have been shaped by the will of others, or how much of their futures will be shaped by forces over which they have no control. Because of this, neither understands or is prepared to undergo the reversals from activity to passivity that will follow upon any choice that they make and that will, overall, characterize the course of their lives. Thus, Oedipus relentlessly and against the advice of others pursues the investigation that leads to his downfall, and Angela, equally relentlessly and equally in the face of conventional wisdom, takes her stand outside the gallery door.
And, as I heard the dream, I sensed that I knew too much and too little as well. We analysts often - perhaps always - know too much and too little. I felt quite sure, for instance, that this was a transference dream, and I was mindful of Angela's association to her worry about the changed hour. I also had a sense that banishing her "knowing" to the dream made it possible for her to abandon her perpetual certainty and to hold, at least for the moment, the worry about not knowing. So much I knew, or thought I knew. But I knew less about the force field that had been created by my asking her to change her appointment; a field that included what I had done to her. I knew the surface reasons, the logistics, that led me to ask her for the change, and I knew that I had been relieved when she had not protested. But I certainly could not convince myself that logistics fully explained why it seemed to me that only by shifting things around with Angela could I make my schedule work. So I couldn't quite say what I had done to her, and I couldn't quite make sense either of what she had noticed or what had worried her. What I had done would, of course, matter less if I were looking at Angela only as the active agent within her dream - that is, if I assumed that she was making of me whatever she needed me to be in the moment. But Angela is also my object, and the dream is also about what she makes of that.

With all this in the air, I neither wanted to nor felt able to do much to interpret the dream; I was skeptical of what would come from any attempt to impose excess rationality on it. So I was content, somewhat at least, to let her newfound access to uncertainty and to the attendant worry stand as an experience about which nothing more needed to be said. Perhaps we could both, for the first time together and most likely for only a brief moment, be patient enough to live with her experience of me as the irrational other. We could do without the soothing.

Both skepticism and patience are aspects of the tragic vision as I have described it. Both emerge from a belief in the impossibility of knowing the meanings of events at the same time that they are happening, and perhaps forever - because all meanings are subject to reversal as life moves on. But both also imply that meanings will accrue as circumstances change - never conclusive meanings, but often interesting ones. The tragic vision forces us out of our certainty, into an openness to what will happen next. It teaches skepticism and patience, and I can't imagine a better prescription for maintaining an analytic attitude. 


\section{References}

1. Sophocles. Oedipus Rex (translated by D. Grene). In: Greene D, Lattimore R, editors. The complete Greek tragedies. Chicago: University of Chicago Press; 1959. vol. 2: Sophocles.

2. Sophocles. Oedipus Tyrannus (translated by R. C. Jebb). In: Easterling PE, editor. Sophocles plays: Oedipus Tyrannus. London: Bristol Classical Press; 1893.

3. Knox B. Oedipus at Thebes: Sophocles' tragic hero and his time. New Haven: Yale University Press; 1957.

4. Jebb R. Introduction to Oedipus Tyrannus. In: Easterling PE, editor. Sophocles Plays: Oedipus Tyrannus. London: Bristol Classical Press; 1893.

5. Sophocles. Oedipus at Colonus (translated by R. Fagles). In: The three Theban plays. New York: Penguin Classics; 1984.

6. Aristotle. Poetics. In: McKeon R, editor. The basic works of Aristotle. New York: Random House; 1941.

7. Schafer R. Retelling a life. New York: Basic Books; 1992.

8. Nietzsche F (1870-1). The birth of tragedy, translated by W. Kaufmann. In: Basic writings of Nietzsche. New York: Modern Library Classics; 2000.

9. Vernant J-P. Tensions and ambiguities in Greek tragedy. In: Vernant J-P, Vidal-Naquet $P$, editors. Myth and tragedy in ancient Greece. New York: Zone Books; 1990.

10. Ahl F. Sophocles' Oedipus: evidence and self-conviction. Ithaca: Cornell University Press; 1991.

11. Statius. Thebaid (translated by A.D. Melville). Oxford: Oxford University Press; 1995.

12. Mendelsohn $\mathrm{D}$. The elusive embrace: desire and the riddle of identity. New York: Knopf; 1999.

13. Freud S. The interpretation of dreams. SE 4, 5. 1900.

14. Freud S. A difficulty in the path of psycho-analysis. SE 17. 1917.
15. Schwartz J. Human action and political action in Oedipus Tyrannos. In: Euben $\mathrm{P}$, editor. Greek tragedy and political theory. Berkeley: University of California Press; 1986. p. 183-209.

16. Segal C. Oedipus Tyrannus: tragic heroism and the limitations of knowledge. London: Oxford University Press; 2001.

17. Lacan J (1966). Ecrits. In: Ecrits: the first complete translation in English (translated by B. Fink). New York: W.W. Norton \& Co.; 2006.

18. Laplanche J. Seduction, translation, and the drives. ICA Documents. 1992.

19. Sullivan HS. The interpersonal theory of psychiatry. New York: W.W. Norton \& Co.; 1953

20. Eissler $\mathrm{K}$. The effect of the structure of the ego on psychoanalytic technique. J Am Psychoanal Assoc. 1953;5:97-121.

21. Ghent E. Masochism, submission, surrender: masochism as a perversion of surrender. Contemp Psychoanal. 1990;26:108-36.

22. Spezzano C. A home for the mind. Psychoanal Quart. 2007;76S:1563-83.

23. Smith $\mathrm{H}$. The analyst's fantasy of the ideal patient. Psychoanal Quart. 2004;73:627-58.

24. Dodds ER (1966). On misunderstanding the Oedipus Rex. In: Segal E, ed. Oxford readings in Greek tragedy. London: Oxford University Press; 1983. p. 177-88.

25. Sullivan HS. Conceptions of modern psychiatry. New York: W.W. Norton \& Co.; 1940.

\section{Correspondence}

Jay Greenberg

275 Central Park West, Apt. 1BB

10024 - New York, NY - USA

E-mail: jaygreenberg275@aol.com 